\title{
World's Largest Mangrove Forest Becoming Plastic Cesspit
}

\author{
Tanveer M. Adyel* and Peter I. Macreadie
}

Centre for Integrative Ecology, School of Life and Environmental Sciences, Deakin University, Melbourne, VIC, Australia

Keywords: Bay of Bengal, blue carbon ecosystem, mangrove, plastic, the Sundarbans

\section{PLASTICS AS NEW CONCERN FOR THE SUNDARBANS}

Plastic is considered as hazardous waste (Rochman et al., 2013) and planetary transboundary pollution (Villarrubia-Gómez et al., 2018; Tessnow-von Wysocki and Le Billon, 2019). Plastics in different forms-including marine litter, plastic debris, meso-plastics, and microplastics-are now ubiquitously distributed in the environment (Jambeck et al., 2015; Napper and Thompson, 2020). The world's largest single mangrove forest, the UNESCO Marine World Heritage-listed Sundarbans between Bangladesh and India, is under immense threat of plastic pollution. A Ramsar site and a Class 3 Tiger Conservation Landscape of global priority for endangered and flagship species Royal Bengal Tiger (Panthera tigris) - the Sundarbans, is historically threatened by many challenges, like over-exploitation, commercial farming and development activities, climate change-induced hazards, and natural disasters (Sen, 2019; Mukul et al., 2020).

Bangladesh and India, the benefit and management sharing countries of the Sundarbans, are ranked among the top twelve mismanaged plastic waste (herein also "plastics") generating nations (Jambeck et al., 2015) and are discharging plastic waste downstream through rivers and coasts (Figure 1A) making the Sundarbans a cesspit for plastic waste. Moreover, this mangrove is formed and modified by the super confluence of the world's 15th longest river Brahmaputra/Jamuna, along the transboundary rivers Ganges/Padma and Meghna. These rivers are among the top ten global plastic waste carriers, transporting over 72,000 tonnes of plastics annually before emptying into the Bay of Bengal (Schmidt et al., 2017). A recent study estimated that the combined flows of the Ganges, Brahmaputra and Meghna rivers can discharge up to 3 billion pieces of microplastics per day into the Bay of Bengal (Napper et al., 2021). Moreover, all the river systems in Bangladesh and India discharge about 4 million tonnes of plastic waste to the Bay of Bengal per annum. The Sundarbans Bangladesh has 177 rivers receiving water from three main rivers and flowing through it to the Bay of Bengal (Banglapedia, 2012) making the Sundarbans as a basin for the long-term accumulation of plastic waste. If current business as usual trend of 2015 and consumer demand for plastic increases with economy continue, Bangladesh and India can generate about 3 and 52 million tonnes of plastics, respectively by 2060 (Figures 1B,C) (Lebreton and Andrady, 2019).

The Bay of Bengal is the largest bay in the world and several littoral countries including Bangladesh, India, Indonesia, Myanmar, Sri Lanka, and Thailand uses its resources. Different river systems of these countries also release plastics to the Bay of Bengal (Figure 1D). Rivers are key vectors for transporting plastics to oceans and bays (Lebreton et al., 2017; Meijer et al., 2021). The discharge of plastics from the littoral countries around the Bay of Bengal is projected to increase up to 5 -times by 2025 compared to that of 2010 (Jambeck et al., 2015). Data-driven mechanistic and Plastics-to-Ocean $\left(\mathrm{P}_{2} \mathrm{O}\right)$ models indicated that over 85 million tonnes of plastics per year can be discharged to the global aquatic systems by the next 20 years if no strong initiatives are taken now in waste management (Borrelle et al., 2020; Lau et al., 2020). Moreover, recently a Lagrangian particle transport model indicated that plastics can be drifted/washed from the oceans to the coasts (Onink et al., 2021). There is a probability of some of these plastics can be drifted or washed toward the 

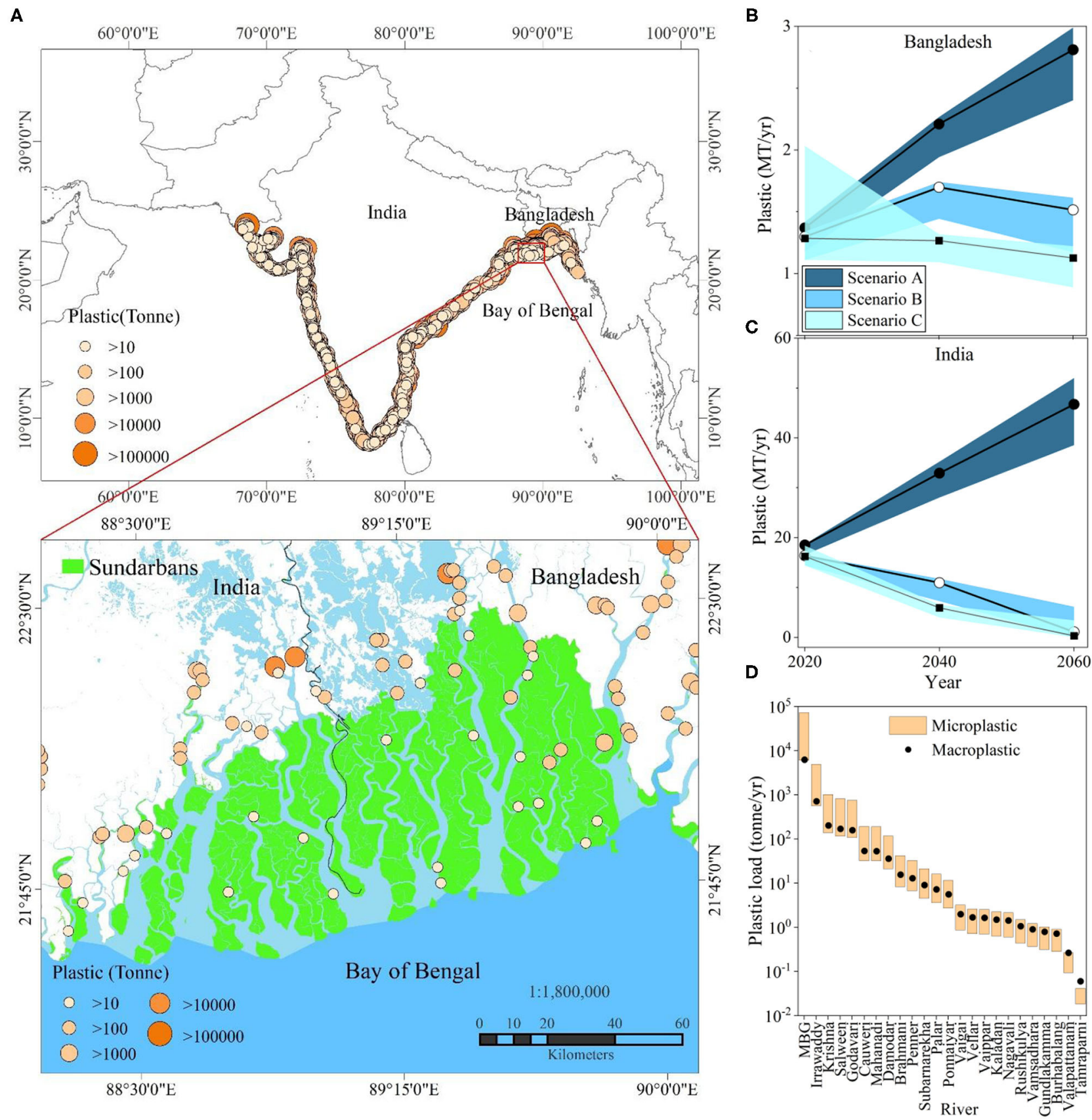

FIGURE 1 | (A) Current status of plastic waste across the coast of India and Bangladesh including the Sundarbans based on Lebreton et al. (2017), (B, C) Possible plastic waste generation in 2020, 2040 and 2060 under three scenarios as per Lebreton and Andrady (2019). Scenario A represents a "business-as-usual" case of 2015 while consumer demand for plastic increases with economy. Scenario B indicates that infrastructures for plastic waste management will advance according to per capita gross domestic product grows. Finally, scenario C corresponds a reduction in plastic demand per capita with fraction of plastic in municipal solid waste capped at 10 and 5\% by 2020 and 2040, respectively as well plastic waste management gradually improves as indicated in scenario B. (D) The discharge of plastic waste as microplastic and macro plastic to the Bay of Bengal through different rivers as per 2017. The lower and upper bar indicates microplastics released based on global model based on data of Schmidt et al. (2017). MBG indicates the Meghna, Brahmaputra and Ganges combined.

nearby Sundarbans from the Bay of Bengal. Discharged transboundary marine litter like fishing net and lost fishing gears within the Bay of Bengal's Exclusive Economic Zones
(Nelms et al., 2021) could also wash into the Sundarbans. Therefore, there is a concern for the integrity of this fragile and diverse ecosystems. 
The Sundarbans mangroves supports around 1,136 animals and 334 plant species (Mukul et al., 2020), comprising 35\% of Bangladesh's biodiversity. These mangrove forests provide unique habitat for breeding and nursing ground of mammals, fishes, turtles, birds, and other exotic species, including threatened, vulnerable or endangered species, e.g., Ganges river dolphin, Irrawaddy dolphin, water monitor lizard, olive ridley turtle, estuarine crocodile, and others. Over 800 marine species are affected by plastics (CBD, 2016), which can occur, for example, through: ingestion; entangled causing severe physical injuries; deaths due to starvation following ingestion; or more subtle effects on behavior and ecological interactions-e.g., the ability to escape from predators or migrate, reducing feeding and depleting energy stores, effects for fertility and growth (Galloway et al., 2017; Napper and Thompson, 2020). Plastics pose the potential to alter wildlife populations and fisheries stocks impairing genetic expression, tissues, reproduction, population size, and community structure (Rochman et al., 2016). Alarmingly, microplastics were found in fish and coral species within the Bay of Bengal and the surrounding area (Hossain et al., 2019; Ghosh et al., 2021). It is estimated that 291 diverse fishery species supported by 177 tidal streams and channels of this forest could be impacted by plastic waste, putting at risk the livelihoods of about 200,000 subsistence fishermen (Sen, 2019). Although microplastics ingestions by biota within the Sundarbans is not reported, however, the scenario is different in the Bay of Bengal. For instance, microplastics are found in gastrointestinal tracts of marine commercial fishes (Hossain et al., 2019) and shrimps (Hossain et al., 2020) collected from the Northern Bay of Bengal at Bangladesh. Microplastics are also reported in zooplankton, and different finfishes and shellfishes collected from Port Blair Bay situated in the Bay of Bengal of Indian territory (Goswami et al., 2020). Therefore, interdisciplinary investigations of plastics and microplastics levels in different trophic levels in the Sundarbans are urgently needed.

Some key features for the local and global significance of the Sundarbans along with plastic issues include:

- Area: About 10,000 km² (Bangladesh: 6,017 km² and India: $4,260 \mathrm{~km}^{2}$ )

- Sanctuaries of the Sundarbans: Sundarbans East, Sundarbans South and Sundarbans West Wildlife Sanctuaries (Bangladesh), Sundarbans National Park and Sajnakhali Wildlife Sanctuary (India)

- Biodiversity (Mukul et al., 2020): Around 334 species of plants. 355 species of birds, 291 species of fishes, 49 species of mammals, 87 species of reptiles, and 14 amphibians

- Dominant floral species (Sen, 2019): Heritiera fomes, Avicennia, Xylocarpus mekongensis, Xylocarpus granatum, Sonneratia apetala, Bruguiera gymnorhiza, Ceriops decandra, Aegiceras corniculatum, Rhizophora mucronate, and Nypa fruticans palms

- Globally threatened, vulnerable or endangered species (Aziz and Paul, 2015; Sen, 2019; Mukul et al., 2020): Royal Bengal Tiger (Panthera tigris), Ganges river dolphin (Platanista gangetica), Irrawaddy dolphin (Orcaella brevirostris), Water monitor lizard (Varanus salvator), Olive ridley turtle (Lepidochelys olivacea), Estuarine crocodile (Crocodilus porosus) and others

- Carbon sink capacity (Atwood et al., 2017; UNESCO, 2020): Soil C stocks (Mg C/ha): about 120 to 180 (Bangladesh) and about 140 to 250 (India). Total soil C stock (Tg C): $20.92 \pm$ 5.11 (Bangladesh) and $19.99 \pm 7.16$ (India)

- Plastic discharge to the Bay of Bengal and through the Sundarbans: To the Bay of Bengal from Bangladesh and India: about 4 million tonnes/yr

- Plastic discharge through the Sundarbans (Lebreton et al., 2017): about $1.7 \times 10^{-8}$ tonnes plastic/ha-yr

Root and sediment within mangroves are efficient at trapping plastics, while root features i.e., density, thickness and height can influence the plastic accumulation and dispersion in the mangroves (Duan et al., 2021). Stationary plastic in forest fringe or sediment can hamper oxygen penetration within the rhizosphere and therefore, create an anoxic condition and subsequently can cause mangrove suffocation (Smith, 2012) leading to pneumatophore deformation or low growth (van Bijsterveldt et al., 2021). Therefore, there is a possibility that the juvenile mosaic of Sterculiaceae and Euphorbiaceae mangroves including Sundari (Heritiera fomes) and looking-glass (Heritiera littoralis) in the Sundarbans could face plastic-induced stress condition that needs further investigation.

The Sundarbans mangrove ecosystem is a major global carbon sink (Atwood et al., 2017). The Sundarbans (Bangladesh) and the Sundarbans National Park (India) mangroves comprise at least 168 million $\mathrm{Mg}$ carbon, and the mangrove area within Bangladesh jurisdiction stores about $28 \%$ of total mangrove carbon stocks within all marine World Heritage sites (UNESCO, 2020). The Sundarbans in Bangladesh and India site can sequester about 118 to 180 and 141 to $252 \mathrm{M} \mathrm{g} \mathrm{C/ha,} \mathrm{respectively}$ (Atwood et al., 2017; UNESCO, 2020). Plastics impact carbon cycling in the terrestrial ecosystem by disrupting soil microbial processes, plant growth, or litter decomposition (Rillig et al., 2021). The waterways within the Sundarbans can transport about $1.7 \times 10^{-8}$ tonne plastic/ha annually from upstream rivers to the Bay of Bengal (Lebreton et al., 2017). Alarmingly, a recent study predicted that global plastic-carbon will be equal to global blue carbon sink by 2035 if the current plastic accumulation trend continues (Stubbins et al., 2021). However, it is not wellestablished whether plastics could hamper carbon sequestration capacity of this mangrove.

The Sundarbans and its resources provide provisional (genetic resources, food and fiber, timer, fuel wood, etc.) services directly and indirectly to 3.5 million people of Bangladesh for their livelihood (Sen, 2019). In addition, 10,000 $\mathrm{km}^{2}$ of the Sundarbans coastline borders India, is supporting a further 4.5 million people. There is a growing demand for tourism within the Sundarbans (Hossain et al., 2021). However, direct plastic dumping by $\sim 250,000$ tourists annually with an increasing number of 30,000 per year just in the Sundarbans Bangladesh-side (Sachin, 2020) is exacerbating forest's threat. Ecosystem services including the aesthetic appeal of mangroves can be hampered due to plastic deposition in the forest floor. Although Bangladesh 
Forest Department is currently working to minimise plastic dumping within the forest floor, conservationists fear that the overall monitoring and enforcement initiatives are not sufficient. Additionally, episodic events can also contribute to plastic accumulation in the Sundarbans. For example, over 26 tonnes of plastics waste from post-cyclone Amphan relief material was discarded from the Indian side in the forest recently (Singh, 2020).

\section{LOOKING FORWARD}

If local and transboundary plastics continue to receive voluntary and undefined support (Borrelle et al., 2017) and downplayed by resource-sharing countries of the Sundarbans, this previously IUCN-advised "heritage in danger (IUCN, 2019)" will be impacted heavily. Although Bangladesh, for the first time in the world, banned the use of thin plastic bag in 2002, but plastic waste management is still a concern for the country (Chowdhury et al., 2020). Cross-border solutions, policy-frameworks, and implementation of action-plans under international environment and development agreements, like the Basel Convention, the United Nations Environment Assembly resolutions on Marine Litter and Microplastics and Agenda 2030 , are immediately needed to protect the last habitat of the endangered Royal Bengal Tigers and other species. For instance, the 2030 Agenda for Sustainable Development Goals calls for action to implement integrated water resources management at all levels, including involvement of transboundary cooperation as appropriate (Target 6.5), protect and restore water-related ecosystems, including forests, wetlands, and rivers (Target 6.6), substantially reduce waste generation through prevention, reduction, recycling and reuse (Target 12.5), and prevent and significantly reduce marine pollution of all kinds, in particular from land-based activities, including marine debris (Target 14.1). The Bay of Bengal Initiative for Multi-Sectoral Technical and Economic Cooperation (BIMSTEC), Joint River Commission, India-Bangladesh Joint Working Group on Conservation of the Sundarbans, and South Asian Association for Regional Cooperation (SAARC) can lead transboundary plastic discharge

\section{REFERENCES}

Atwood, T. B., Connolly, R. M., Almahasheer, H., Carnell, P. E., Duarte, C. M., Lewis, C. J. E., et al. (2017). Global patterns in mangrove soil carbon stocks and losses. Nat. Clim. Chang. 7, 523-528. doi: 10.1038/nclimate 3326

Aziz, A., and Paul, A. R. (2015). Bangladesh sundarbans: present status of the environment and biota. Diversity 7, 242-269. doi: 10.3390/d703 0242

Banglapedia (2012) National Encyclopedia of Bangladesh, 2nd edn. Bangladesh: Asiatic Society of Bangladesh. Available online at: https://en.banglapedia.org/ index.php/River (accessed August 30, 2021).

Borrelle, S. B., Ringma, J., Law, K. L., Monnahan, C. C., Lebreton, L., McGivern, A., et al. (2020). Predicted growth in plastic waste exceeds efforts to mitigate plastic pollution. Science 369, 1515-1518. doi: 10.1126/science.aba3656

Borrelle, S. B., Rochman, C. M., Liboiron, M., Bond, A. L., Lusher, A., Bradshaw, H., et al. (2017). Opinion: why we need an international agreement minimisation and raise public awareness on plastic pollution. Local and national responses, like effective eco-tourism, plastic sorting and disposal program, and inclusive and participatory decision-making and forest-management/conservation are also critical to protect the future of this invaluable blue carbon ecosystem. Plastics reduction approaches at local level have recently been suggested (Lebreton and Andrady, 2019; Lau et al., 2020; Simon et al., 2021). For instance, Lebreton and Andrady (2019) proposed a scenario (Scenario B) where facilities or infrastructures for plastic waste management need to be improved according to per capita gross domestic product grows (Figure 1B). In addition to Scenario B, the portion of plastic waste in overall municipal solid waste needs to be lowered at 10 and $5 \%$ by 2020 and 2040, respectively (Scenario C), (Figure 1C), (Lebreton and Andrady, 2019). Therefore, we call the countries sharing the Sundarbans and Bay of Bengal to: eliminate plastic discharge to the environment; reduce plastic production; improve plastic waste collection and recycling infrastructure; and develop public awareness on plastic waste control. Periodic plastic clean-up program needs to strengthen to remove existing plastic waste in the environment and block the plastic discharge downstream. Strong monitoring and incentive scheme for the organisation involved with plastics recycling needs to be encouraged.

\section{AUTHOR CONTRIBUTIONS}

TA: conceptualization, funding acquisition, data curation, formal analysis, writing-original draft, writing-review, and editing. PM: writing-original draft, writing-review and editing, resources, supervision, and project administration. All authors contributed to the article and approved the submitted version.

\section{FUNDING}

TA received support from the Deakin University under the Alfred Deakin Postdoctoral Research Fellowship (ADPRF) scheme and ECR Enabler Grant. on marine plastic pollution. Proc. Nat. Acad. Sci. U.S.A. 114, 9994-9997. doi: 10.1073/pnas.1714450114

CBD (2016). Marine Debris: Understanding, Preventing and Mitigating the Significant Adverse Impacts on Marine and Coastal Biodiversity. Technical Series No.83. Montreal: Secretariat of the Convention on Biological Diversity.

Chowdhury, G. W., Koldewey, H. J., Duncan, E., Napper, I. E., Niloy, M. N. H., Nelms, S. E., et al. (2020). Plastic pollution in aquatic systems in Bangladesh: a review of current knowledge. Sci. Total Environ. 761:143285. doi: $10.1016 /$ j.scitotenv.2020.143285

Duan, J., Han, J., Cheung, S. G., Chong, R. K. Y., Lo, C.-M., Lee, F. W.-F., et al. (2021). How mangrove plants affect microplastic distribution in sediments of coastal wetlands: case study in Shenzhen Bay, South China. Sci. Total Environ. 767:144695. doi: 10.1016/j.scitotenv.2020.144695

Galloway, T., Cole, M., Lewis, C., Atkinson, A., and Allen, J. (2017). Interactions of microplastic debris throughout the marine ecosystem. Nat. Ecol. Evol. 1:116. doi: 10.1038/s41559-017-0116 
Ghosh, G. C., Akter, S. M., Islam, R. M., Habib, A., Chakraborty, T. K., Zaman, S., et al. (2021). Microplastics contamination in commercial marine fish from the Bay of Bengal. Reg. Stud. Mar. Sci. 44:101728. doi: 10.1016/j.rsma.2021.101728

Goswami, P., Vinithkumar, N. V., and Dharani, G. (2020). First evidence of microplastics bioaccumulation by marine organisms in the Port Blair Bay, Andaman Islands. Mar. Pollut. Bull. 155:111163. doi: 10.1016/j.marpolbul.2020.111163

Hossain, M., Ahmed, M., Islam, T., Uddin, M. Z., Ahmed, Z. U., and Saha, C. (2021). Paradigm shift in the management of the Sundarbans mangrove forest of Bangladesh: issues and challenges. Trees Forests People 5:100094. doi: $10.1016 /$ j.tfp.2021.100094

Hossain, M. S., Rahman, M. S., Uddin, M. N., Sharifuzzaman, S., Chowdhury, S. R., Sarker, S., et al. (2020). Microplastic contamination in Penaeid shrimp from the Northern Bay of Bengal. Chemosphere 238:124688. doi: 10.1016/j.chemosphere.2019.124688

Hossain, M. S., Sobhan, F., Uddin, M. N., Sharifuzzaman, S., Chowdhury, S. R., Sarker, S., et al. (2019). Microplastics in fishes from the Northern Bay of Bengal. Sci. Total Environ. 690, 821-830. doi: 10.1016/j.scitotenv.2019.07.065

IUCN (2019). IUCN Advises “in Danger" Status for Three World Heritage sites. International Union for Conservation of Nature. Available online at: https:// www.iucn.org/news/iucn-43whc/201906/iucn-advises-danger-status-threeworld-heritage-sites (accessed August 30, 2021).

Jambeck, J. R., Geyer, R., Wilcox, C., Siegler, T. R., Perryman, M., Andrady, A., et al. (2015). Plastic waste inputs from land into the ocean. Science 347, 768-771. doi: 10.1126/science. 1260352

Lau, W. W., Shiran, Y., Bailey, R. M., Cook, E., Stuchtey, M. R., Koskella, J., et al. (2020). Evaluating scenarios toward zero plastic pollution. Science 369, 1455-1461. doi: 10.1126/science.aba9475

Lebreton, L., and Andrady, A. (2019). Future scenarios of global plastic waste generation and disposal. Palgrave Commun. 5, 1-11. doi: 10.1057/s41599-018-0212-7

Lebreton, L. C., Van Der Zwet, J., Damsteeg, J.-W., Slat, B., Andrady, A., and Reisser, J. (2017). River plastic emissions to the world's oceans. Nat. Commun. 8, 1-10. doi: 10.1038/ncomms15611

Meijer, L. J., van Emmerik, T., van der Ent, R., Schmidt, C., and Lebreton, L. (2021). More than 1,000 rivers account for $80 \%$ of global riverine plastic emissions into the ocean. Sci. Adv. 7:eaaz5803. doi: 10.1126/sciadv.aaz5803

Mukul, S. A., Huq, S., Herbohn, J., Seddon, N., and Laurance, W. F. (2020). Saving the sundarbans from development. Science 368, 1198-1198. doi: $10.1126 /$ science.abb 9448

Napper, I. E., Baroth, A., Barrett, A. C., Bhola, S., Chowdhury, G. W., Davies, B. F., et al. (2021). The abundance and characteristics of microplastics in surface water in the transboundary Ganges River. Environ. Pollut. 274:116348. doi: 10.1016/j.envpol.2020.116348

Napper, I. E., and Thompson, R. C. (2020). Plastic debris in the marine environment: history and future challenges. Glob. Chall. 4:1900081. doi: $10.1002 / \mathrm{gch} 2.201900081$

Nelms, S. E., Duncan, E. M., Patel, S., Badola, R., Bhola, S., Chakma, S., et al. (2021). Riverine plastic pollution from fisheries: Insights from the Ganges River system. Sci. Total Environ. 756:143305. doi: 10.1016/j.scitotenv.2020.143305

Onink, V., Jongedijk, C. E., Hoffman, M. J., van Sebille, E., and Laufkötter, C. (2021). Global simulations of marine plastic transport show plastic trapping in coastal zones. Environ. Res. Lett. 16:064053. doi: 10.1088/1748-9326/abecbd

Rillig, M. C., Leifheit, E., and Lehmann, J. (2021). Microplastic effects on carbon cycling processes in soils. PLoS Biol. 19:e3001130. doi: 10.1371/journal.pbio.3001130
Rochman, C. M., Browne, M. A., Halpern, B. S., Hentschel, B. T., Hoh, E., Karapanagioti, H. K., et al. (2013). Classify plastic waste as hazardous. Nature 494, 169-171. doi: 10.1038/494169a

Rochman, C. M., Browne, M. A., Underwood, A. J., Van Franeker, J. A., Thompson, R. C., and Amaral-Zettler, L. A. (2016). The ecological impacts of marine debris: unraveling the demonstrated evidence from what is perceived. Ecology 97, 302-312. doi: 10.1890/14-2070.1

Sachin, S. (2020). Annual Visitor Arrivals at Sundarbans Rise to 250,000 but Drawbacks Remain. Available online at: https://www.bdnews24.com (accessed August 30, 2021).

Schmidt, C., Krauth, T., and Wagner, S. (2017). Export of plastic debris by rivers into the sea. Environ. Sci. Tech. 51, 12246-12253. doi: 10.1021/acs.est.7b02368

Sen, H. (2019). The Sundarbans: A Disaster-Prone Eco-Region. Berlin: Springer. doi: 10.1007/978-3-030-00680-8

Simon, N., Raubenheimer, K., Urho, N., Unger, S., Azoulay, D., Farrelly, T., et al. (2021). A binding global agreement to address the life cycle of plastics. Science 373, 43-47. doi: 10.1126/science.abi9010

Singh, G. (2020). Plastic Waste From Post-Amphan Relief Material Could Add to Pollution in Sundarbans. Menlo Park, CA: MONGABAY.

Smith, S. D. (2012). Marine debris: a proximate threat to marine sustainability in Bootless Bay, Papua New Guinea. Mar. Pollut. Bull. 64, 1880-1883. doi: 10.1016/j.marpolbul.2012.06.013

Stubbins, A., Law, K. L., Muñoz, S. E., Bianchi, T. S., and Zhu, L. (2021). Plastics in the Earth system. Science 373, 51-55. doi: 10.1126/science. abb0354

Tessnow-von Wysocki, I., and Le Billon, P. (2019). Plastics at sea: treaty design for a global solution to marine plastic pollution. Environ. Sci. Policy 100, 94-104. doi: 10.1016/j.envsci.2019.06.005

UNESCO (2020). UNESCO Marine World Heritage: Custodians of the Globe's Blue Carbon Assets. Paris: UNESCO.

van Bijsterveldt, C. E., van Wesenbeeck, B. K., Ramadhani, S., Raven, O. V., van Gool, F. E., Pribadi, R., et al. (2021). Does plastic waste kill mangroves? A field experiment to assess the impact of macro plastics on mangrove growth, stress response and survival. Sci. Total Environ. 756:143826. doi: $10.1016 /$ j.scitotenv.2020.143826

Villarrubia-Gómez, P., Cornell, S. E., and Fabres, J. (2018). Marine plastic pollution as a planetary boundary threat-The drifting piece in the sustainability puzzle. Mar. Policy 96, 213-220. doi: 10.1016/j.marpol.2017.11.035

Conflict of Interest: The authors declare that the research was conducted in the absence of any commercial or financial relationships that could be construed as a potential conflict of interest.

Publisher's Note: All claims expressed in this article are solely those of the authors and do not necessarily represent those of their affiliated organizations, or those of the publisher, the editors and the reviewers. Any product that may be evaluated in this article, or claim that may be made by its manufacturer, is not guaranteed or endorsed by the publisher.

Copyright $\odot 2021$ Adyel and Macreadie. This is an open-access article distributed under the terms of the Creative Commons Attribution License (CC BY). The use, distribution or reproduction in other forums is permitted, provided the original author(s) and the copyright owner(s) are credited and that the original publication in this journal is cited, in accordance with accepted academic practice. No use, distribution or reproduction is permitted which does not comply with these terms. 